\title{
COASTAL SUSTAINABLE DEVELOPMENT STUDIES IN LATVIA: INTEGRATED LOCAL SOCIAL-ECOLOGICAL SYSTEMS GOVERNANCE
}

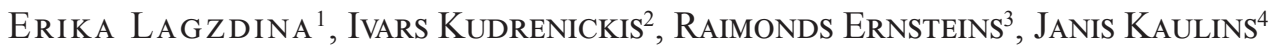 \\ University of Latvia (Latvia)
}

\begin{abstract}
Importance of sustainable coastal governance also in the Baltic sea region has been widely recognised and since such governance has to have integrative nature that requires horizontal cross-sectorial integration as well as involvement of all governance levels and subsequently organisation of vertical integration among the levels. Besides some succesfull local cases around Europe, mainly special outside projects based, there is to be recognized that the municipal integrated sustainable coastal governance has not been yet neither well and widely locally developed in practice nor sufficiently researched field in order to permit necessary design of adequate policy innovations. Practical development and local realisation of the municipal integrated coastal governance often encounters obstacles of the basic nature, e.g. because there are not sufficiently understood and applied cross- and trans-disciplinary approaches - studies and governance of the coastal territories as the complex social-ecological systems (SES). For understanding the process and structure of coastal governance, application of system thinking and system dynamics methods are to be emphasized as well. The paper demonstrates adaptation of coastal nature studies based System Analysis Framework (SAF) methodology for its application to coastal governance studies and general municipal governance system adjusting and upgrading towards coastal issues, what could be seen as the new step for SAF further planned developments. As the part of the EU BONUS programme BaltCoast project, the authors performed, including main stakeholders participation elements, the issue identification step, system definition and also a conceptual model building steps of the SAF methodology application in the particular, local governance innovations rich, case study territory - Salacgriva municipality in Latvia. Coastal governance problems in Latvia are especially relevant for rural coastal municipalities with limited administrative capacities and long and low populated coastline territories. The next SAF application steps will include development of coastal governance system scenarios using a systems modelling tool and the design and testing of complementary set of governance instruments as science-policy interface, that shall support sustainable use of coastal resources in the interests of coastal nature and culture protection, and local socio-economic development.
\end{abstract} KEYWORDS: coastal governance and resources, social-ecological system, stakeholders, system analysis framework.

JEL CODES: Q, Q5, Q56, Q58

1 Erika Lagzdina - University of Latvia, Department of Environmental Science, Environmental Governance and Communication E-mail: erika.lagzdina@lu.lv Tel. +37126551438

2 Ivars Kudrenickis - University of Latvia, Department of Environmental Science, Environmental and Climate Change Governance

E-mail: ivars.kudrenickis@1u.lv

3 Raimonds Ernšteins - University of Latvia, Department of Environmental Science, Environmental and Coastal Governance E-mail: raimonds.ernsteins@1u.lv

4 Janis Kauliņ̌s - University of Latvia, Department of Environmental Science, Environmental Governance and Indicator Systems E-mail: janis.kaulins@lu.lv 


\section{Introduction}

Coastal marine-terrestrial systems are based on interconnected elements of complex resources systems consisting of all sustainability dimentions as natural, socio-economic and governance resources - coastal territories are to be seen as social-ecological systems (SES). Instability of the coastal systems that can be interpreted in terms of quality and quantity of resources and the system's ability to provide eco-system services, including resilience to climate changes, is caused by inadequate use, protection and management of the coastal territories in general. There is a need for a systemic approach and the instruments that would support our ability to understand, simulate, and communicate changes in the coastal systems, and respond adequately through the governance sub-system, including stakeholders and a whole set of governance instruments.

The scientific problem discussed in the paper analyses how to improve the coastal governance process and decision making procedure. Evidently, such an improvement shall be based on two principles: high quality information, provided by science research/studies, and multi-stakeholder involvement. To unite both these requirements in a comprehensive tool, the System Analysis Framework (SAF) methodology had been developed and tested via application of it at 18 coastal study sites within the SPICOSA project (Hopkins, et al., 2012). The SAF is ment to be a tool for the transition to sustainable development in coastal systems. The knowledge gained from SAF applied experiments concerns the practical aspects for the development: governance in terms of policy effectiveness; sustainability science in terms of applying transdisciplinary science to social-ecological problems; simulation analysis in terms of quantifying dysfunctions in complex systems; partnership among research, management, and stakeholders as for a quantitative basis for collaborative decision making (Hopkins, et al., 2012).

The paper presents the testing results by the University of Latvia research team of the SAF application for providing governance options in the complex coastal governance systems, which overcomes the borders of the single located, if even interconnected, problems. The application of SAF for analysis of the coastal governance system development, in comparison to mainly known nature systems governance studies, is a certain innovation in the SAF's application into practice. In order to elaborate governance options, the preconditions are - balanced sharing of information with stakeholders, creation of space for common dialogue and repeated (issue-by-issue) communication with stakeholders (Mette, 2011). In such understanding, the SAF contribution to coastal governance development is dedicated to understanding and diagnosing, but not to providing the end-user with "panacea" - this is an important difference, as the end-user is a partner in the coastal governance options development process (Ostrom et al., 2007). At the same time, as underlined by E. Ostrom (2009), the system specific monitoring and compatible multidisciplinary databases are essential precondition as well as the need to increase the capacity for governance problems analysis.

\section{Coastal rural municipality case study: Salacgriva municipality site}

The length of the Latvian coastline is about $500 \mathrm{~km}$. It provides a living space for about 0.9 million people that consitutes $45 \%$ of the country's population. Four out of the total of 17 municipalities on the coast are considerably large cities, where $91 \%$ of the coastal permanent residents live. Other $9 \%$ of the population live in small and medium size rural municipalities with respective life style, production and land use patterns.

Generally, substantial part of the coastal area and its natural resources in Latvia are located in the low population density territories. Therefore, for analysis of the coastal governance processes, structure building elements, and instruments, it was essential to select an adequate case study. Salacgriva municipality belongs to a group of small rural municipalities and is representative in this respect. The municipal coastline stretches for $55.5 \mathrm{~km}$. It is one of the longest municipal shore lines in the country. The total area of the municipality is $638 \mathrm{~km}^{2}$ and the population size is ca. 7800 inhabitants, out of whom more than one third lives in the town named Salacgriva. Population density in Salacgriva municipality is 12 residents per $\mathrm{km}^{2}$ that is almost three times below the average value in the country. Removing Salacgriva and Ainazi towns from the statistics, population density in the remaining rural areas is only 7 residents per $\mathrm{km}^{2}$. Moreover, since 2009 the size of 
the population decreases and $10 \%$ decrease (in absolute figures it makes 900 people) was fixed in years until 2015. Such trend is very typical to the rural areas of the territory. This indicates rapid loss in the coastal local human capital.

Exploration of the coastal situation in the municipality allows to identify characteristics of the territory that are relevant to the coastal resources management (they are grouped in three blocks based on the coastal socio-ecological system approach).

\subsection{Nature and culture resources}

There is a considerably strict nature protection regime as the municipality is located in the North Vidzeme Biosphere Reserve - a specially protected nature territory administered by the state run Nature Protection Agency. Four nature reserves with strict regimes are located directly in the coastal zone, three of them belong to the Nature 2000 sites. All coastal area is under landscape protection or buffer zone regime. Adjacent areas are under the neutral regime, and thus human activities are generally allowed there. Three rivers (Salaca, Svetupe, and Vitrupe) provide a native Baltic salmon for habitats, meanwhile, Salaca is used by the water tourists. Besides, there are numerous cultural and industrial heritage sites.

\subsection{Economic resources}

The main local economy sectors are agriculture, forestry, fishery, tourism, and retail. Almost one third of the land is used for agriculture. Thus, a risk of water pollution due to the river runoffs shall be considered under control. Moreover, $53 \%$ of the land belong to the private sector owners ( $85 \%$ to private persons), about $39 \%$ (mostly forest lands) belong to the State. The State is a legal owner of the beach. In 2015, Law on Land Governance stipulated rights of the municipalities to manage coastal territories within their administrative boundaries, unless lands are no longer governed by the state institutions (ministries). As municipality is not the main landowner in this situation, it is essential to develop partnership with other landowners and stakeholders to ensure the use of resources and sustainable coastal management.

The municipality is crossed and actually physically is split into two parts by the international motorway ViaBaltica with high traffic intensity and heavy transit flows. That creates additional stress to the coastal resources. However, this transit road provides opportunities for tourism, as distance to the neighbouring Estonia and Lithuania and their capitals is moderate. Local asphalted roads connect Salacgriva municipality with the regional center of North Vidzeme in Valmiera that is located $94 \mathrm{~km}$ inland. In future, an important infrastructure element will be the projected international railway Rail Baltica.

There are two ports in the area: Salacgriva trading port and Kuivizi yacht port. The dominating type of cargos in Salacgriva are of forestry and wood production. The both ports taken together can accept 45 yachts. Besides, Kuivizi port owns a Blue Flag certificate for its environmental performance. The important asset is the European cycling rote "Iron Curtain Trail" along the coast.

\subsection{Social and governance resources}

A unique local governance element is the "Villages leaders" institution that provides reciprocal link between the central administration and the village people. It maintains information flow and assists communities in solving their daily problems. "Villages leaders" are established also as the municipal consultative council and shall evolve as a critical link for involvement of the local people in the coastal development activities.

There are several types of local NGOs, though their activities are mostly orientated to small interest groups, and they are limited in size and insufficienty coordinated. The Youth organization and Entrepreneurs Council takes an active part in the local decision making. Also quite a number of village development based NGOS's are to be mentioned particularly. There is need to link disperse NGO and business efforts on the co- 
ast by enhancing mutually beneficial cooperation. The role of formal and, especially, non-formal educational sector (tourism information centre, libraries, museums) currenty is to raise public environmental awareness and to provide not only coastal information, but also whole set of coastal communition instruments - besides information, also education/training, participation and environmentally responsible behavior.

The situation analysis shows that the capacity and resources of the Salacgriva municipality for adequate governance of the coastal resources are insufficient. Thus, the main governance principle for the sustainable coastal governance should be based on collaboration and use of other stakeholders' / society's capacity (resources). This is relevant for other Latvian coastal rural municipalities as well.

Salacgriva municipality was selected for the case study because of its diverse coastal resources that provide sufficient material for analysis and application of the system analysis methodology. Besides, it is a unique case from a perspective of coastal governance elements that create a set of preconditions for testing coastal governance approaches and ensuring involvement of local stakeholders in problem solving. Taking into account specifics of the municipality, it was decided to focus the research on finding the answers on how to improve coastal governance system based on collaboration among stakeholders that are a key driving force for integrated and sustainable coastal management that consists of protection, use and development of coastal socio-economic, natural and cultural resources.

\section{Research methodology and approach}

Significance of the environmental, economic, social, and cultural value of the coast is widely recognised. This is a space, a resource and a source of ecosystem services and serves for well-being of the society. Coastal territories are vulnerable to the impacts from the global processes (climate change, pollution etc.), besides they are subjects to pressure from human activities on land and in the sea. Human activities are driven by the interests of different stakeholders, which may contradict, what causes additional pressure on the coastal resources. On the other hand, a coast is a territory of the interaction of diverse human needs: needs of local coastal citizens (permanent residents and newcomers); needs of visitors (short term visitors as one day tourists, by-passers, and long term visitors who stay and use local resources and services); and needs of human society (which are represented and safeguarded by the national state institutions and environmental NGOs). Each of these groups focuses on particular resources which serve the best for satisfaction of their needs. As a result, coastal resources management is unsustainable and as such it cannot serve for society either at the national or local (municipal) level.

The SAF provides a research methodology to investigate functions of systems in order to stimulate specific questions concerning their function (Hopkins et al., 2011). It provides a tool to use scientific knowledge in support of decision-making on the coastal zone management. The SAF is a holistic, issue oriented investigation that allows to overcome barriers created by separation of ecological, social, economic, and governance systems. The SAF application for a particular case study, which is described in this paper, include the following steps: 1) issue identification and stakeholders' analysis; 2) system definition; 3) conceptual model design. Based on the local situation and coastal policy processes in Latvia, the eight steps approach to the project implemetation were designed by the research team (Figure 1).

The national level governance system (national 'top-down' approach) usually works as an external driving force that provides guidance for stakeholders at all levels. The Sustainable Development Strategy of Latvia until 2030 acknowledges that the Baltic Sea coast is a unique area of national interest, where preservation of nature and cultural heritage should be balanced with the economic development. The National mid term Strategy for Coastal Spatial Development for 2011-2017 envisages development of the coast as a multifunctional space where appropriate infrastructure serves for development and adaptation to climate change. A National Long-Term Thematic Plan for the Coastal Area of the Baltic Sea states two national priorities: coastal infrastructure and collaborative governance. 


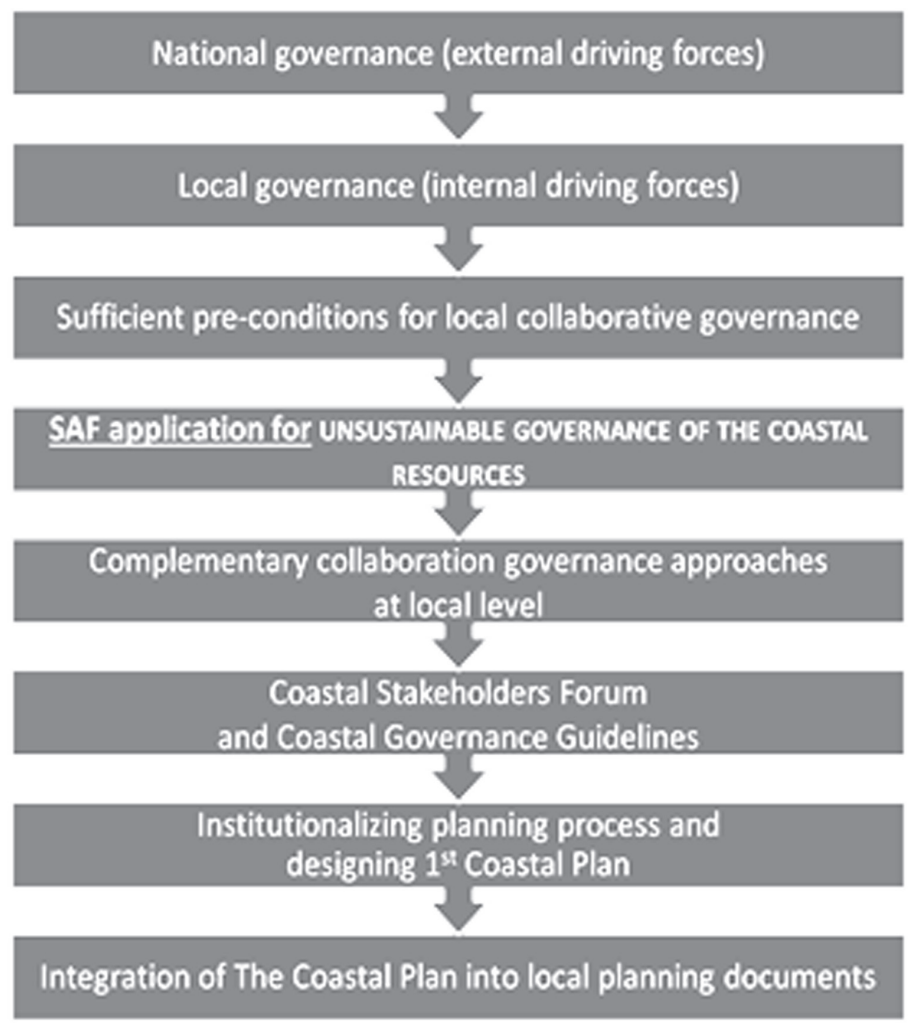

Figure 1. Stepwise approach for the research and development of the coastal resource governance system

The local level governance system (local 'top-down' approach) is underdeveloped at both planning and implementation levels. Initial studies identify the insufficient link also between national and local level planning documents. Generally, local planning is not very much related to the coastal issues, and as a result, activities to secure integrated coastal management at local level are quite limited. However, noteworthy that Salacgriva pioneered in Latvia by adopting the Green Municipality Declaration in 2010 and Climate Change Adaptation Strategy in 2011. All municipalities since 2014/2015 do have a mandatory Sustainable Development Strategy until 2030 as well. The mentioned documents include coastal issues. However, the municipality is currently starting to work on the Spatial Plan for 2017-2027 and this provides opportunity for integration of coastal issues and for the stakeholders' discussions on better governance of the costal resources. Also, mentioned above, pioneering 'bottom-up' approach elements do continue developments, supported by municipality leadership.

Studies done and stakeholders's consultations have been stressing necessity to facilitate collaboration governance approach for the coastal resources governance (complementary 'top-down' and 'bottom-up' approaches), and, based on this, to develop a set of coastal governance instruments. The process starts with a comprehensive assessment of four elements of the coastal social-ecological system (SES), i.e., natural (ecological), social and cultural, economic and governance resources.

\section{Application of SAF in coastal governance studies}

\subsection{Issue identification}

The issue identification step started with desk studies that provided wide knowledge about the integration of coastal issues into various policies and territorial planning documents, and allowed to conclude that there 
is a lack of coastal management instruments at all governance levels; human and institutional capacity and public awareness of coastal issues is insufficient, and stakeholders' interest in efficient and sustainable use of the coastal resources and coastal potential in general is also low. The method for issue identification was based on the iterative multi-step approach (Figure 2.) with numerous tools applied for indepth investigations (e.g., field studies, surveys, and stakeholders seminars). Each next step extended the understanding of the researchers and participants on the coastal issues and supplemented or even modified earlier results/conlcusions.

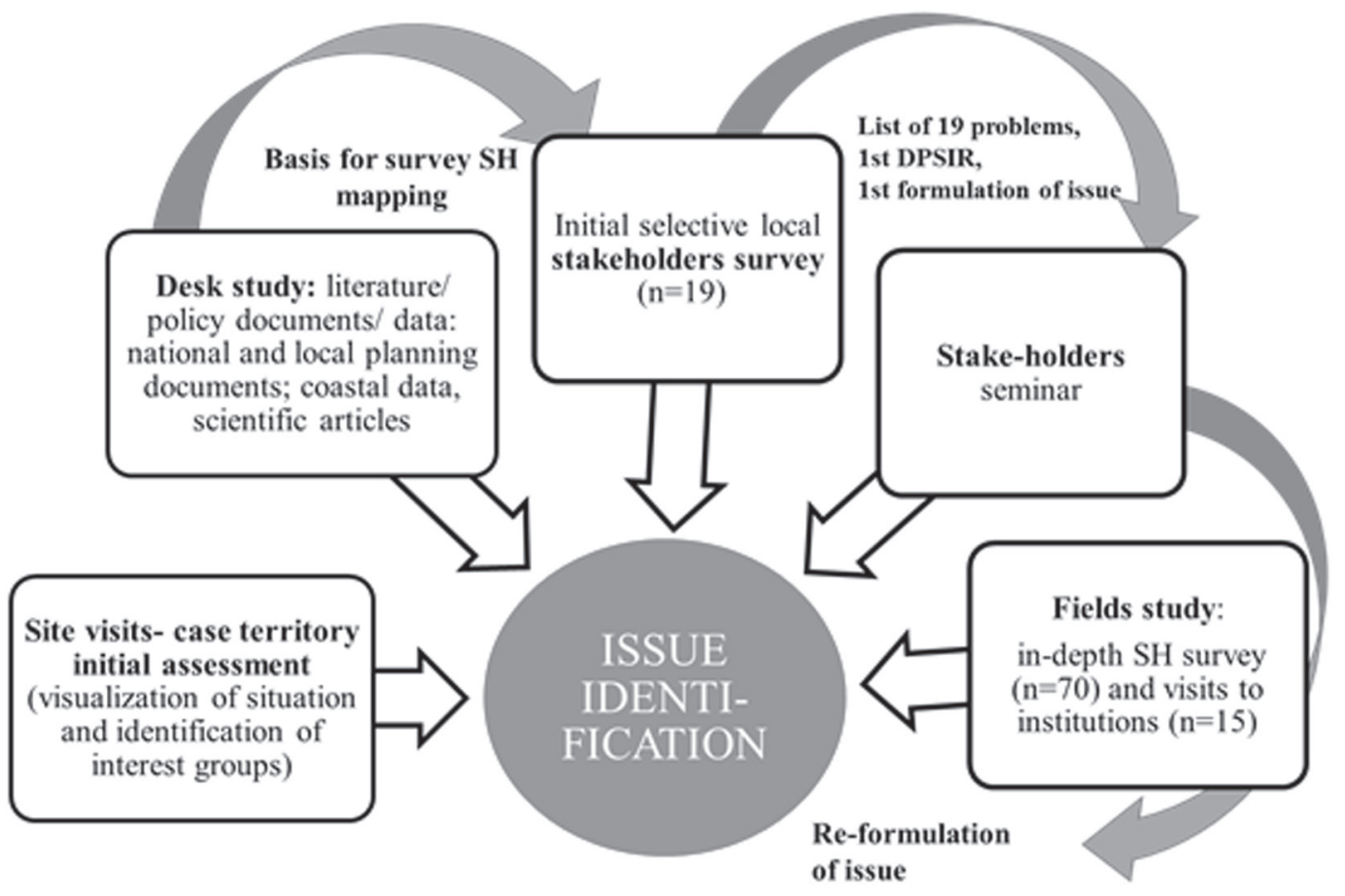

Figure 2. The iterative issue identification process

The information gathered from desk studies and social surveys provided a basis for expert brainstorming exercise that resulted in a list of 16 priority problems. The SAF methodology envisages a detailed analysis of the human activities that cause problems and identification of the role of stakeholders' groups in respect to those problems. After summing up all interlinkages, inter-dimensional elements, relation to the ecosystem services and involvement of stakeholders (Table 1), a final list of 19 problems was developed. For further analysis, it was broken into five clusters depending on problem complexity and relationship with stakeholders. Another SAF element was the DPSIR approach (Drivers-Pressures-State-Impacts-Responses) that was used to analyse the cause-effect chains within the coastal system. The DPSIR analysis logic in this case was based on categories of needs represented by the three main stakeholders groups: local citizens, visitors, and the wider human society. 
Table 1. Multi-criteria analysis of coastal problems (stakeholders' dimension)

\begin{tabular}{|c|c|c|}
\hline Problems & $\begin{array}{l}\text { Stakeholders causing } \\
\text { problems }\end{array}$ & Stakeholders interested in solving problems \\
\hline $\begin{array}{l}\text { Restricted access to the sea: dense } \\
\text { coastal residential construction } \\
\text { structure. Private property rights }\end{array}$ & $\begin{array}{l}\text { Landowners }\left(1^{\text {st }} \text { building }\right. \\
\text { line) }\end{array}$ & $\begin{array}{l}\text { Local administration; Local population; Local } \\
\text { community organizations; The next building } \\
\text { line landowners; Beach visitors }\end{array}$ \\
\hline Coastal (ground cover) erosion & $\begin{array}{l}\text { Local people; } \\
\text { Visitors; Owners of vehicles }\end{array}$ & $\begin{array}{l}\text { Local administration; Visitors; State } \\
\text { environmental institutions; Local population } \\
\text { NGOs / Environmental NGOs }\end{array}$ \\
\hline $\begin{array}{l}\text { Limited access to the coast for people } \\
\text { with special needs }\end{array}$ & $\begin{array}{l}\text { Project managers, services } \\
\text { business }\end{array}$ & $\begin{array}{l}\text { Local administration; Handicapped persons } \\
\text { and their families; NGO }\end{array}$ \\
\hline $\begin{array}{l}\text { Coast erosion: winds, storms, damage } \\
\text { to roads, risk to property and public } \\
\text { infrastructure }\end{array}$ & $\begin{array}{l}\text { Visitors, Landowners, } \\
\text { Entrepreneurs }\end{array}$ & $\begin{array}{l}\text { Local administration; Landowners; } \\
\text { Entrepreneurs; Road users; Insurance } \\
\text { companies; Local population }\end{array}$ \\
\hline $\begin{array}{l}\text { Overflooding of some territories } \\
\text { causing risk of property damage and } \\
\text { risk of pollution of drinking water }\end{array}$ & $\begin{array}{l}\text { Local administration, } \\
\text { Households }\end{array}$ & $\begin{array}{l}\text { Local administration; Landowners; } \\
\text { Entrepreneurs; Insurance companies }\end{array}$ \\
\hline $\begin{array}{l}\text { Risk of degradation of valuable coastal } \\
\text { biotopes (Natura } 2000 \text { sites) }\end{array}$ & & $\begin{array}{l}\text { Landowners; State environmental institutions; } \\
\text { NGOs; Visitors }\end{array}$ \\
\hline $\begin{array}{l}\text { Bad sea water quality: limited water } \\
\text { exchange in some places, blue algae }\end{array}$ & & Local population; Visitors \\
\hline $\begin{array}{l}\text { Human safety in bathing /swimming } \\
\text { places }\end{array}$ & & $\begin{array}{l}\text { Local administration; Local population; } \\
\text { Visitors; State health institutions; State rescue } \\
\text { and safety service }\end{array}$ \\
\hline $\begin{array}{l}\text { Nutrients }(\mathrm{N}, \mathrm{P}) \text { pollution load from } \\
\text { rivers }\end{array}$ & Farmers & $\begin{array}{l}\text { Local administration; Fishermen; NGO; } \\
\text { Visitors }\end{array}$ \\
\hline $\begin{array}{l}\text { Pollution form individual households' } \\
\text { untreated wastewaters }\end{array}$ & Individual households & $\begin{array}{l}\text { Local administration; Fishermen; NGO; } \\
\text { Visitors; State environmental institutions }\end{array}$ \\
\hline $\begin{array}{l}\text { Potential pollution from industrial } \\
\text { sites. Improper transport operations }\end{array}$ & Salacgriva port firms & $\begin{array}{l}\text { Landowners; State environmental institutions; } \\
\text { NGO }\end{array}$ \\
\hline $\begin{array}{l}\text { Forest damage risks due to storms, } \\
\text { fires etc. }\end{array}$ & & $\begin{array}{l}\text { Forest owners; Forest managers; Local } \\
\text { administration; NGOs }\end{array}$ \\
\hline Marine litter & $\begin{array}{l}\text { Visitors; } \\
\text { Ship owners; Entrepreneurs }\end{array}$ & $\begin{array}{l}\text { Local administration; Visitors; Entrepreneurs; } \\
\text { NGOs and community organizations; Local } \\
\text { population }\end{array}$ \\
\hline $\begin{array}{l}\text { Risk of degradation of nature and } \\
\text { culture capital }\end{array}$ & - & $\begin{array}{l}\text { Entrepreneurs; Craftsmen; Local population; } \\
\text { Local administration; Visitors; Development } \\
\text { and interests groups NGOs/ Envir.NGO }\end{array}$ \\
\hline High local seasonal pressures & Visitors & $\begin{array}{l}\text { Local administration; Entrepreneurs; } \\
\text { Landowners }\end{array}$ \\
\hline $\begin{array}{l}\text { Construction of residential buildings } \\
\text { on coast }\end{array}$ & Landowners & $\begin{array}{l}\text { Local administration; Local people; Local } \\
\text { community organizations; The next building } \\
\text { line landowners; Entrepreneurs; Visitors }\end{array}$ \\
\hline $\begin{array}{l}\text { Insufficiently managed coastal } \\
\text { territories with low population density }\end{array}$ & $\begin{array}{l}\text { Local administration } \\
\text { Local people }\end{array}$ & $\begin{array}{l}\text { Local municipality; Environmental NGO; } \\
\text { State environmental institutions; Landowners; } \\
\text { Entrepreneurs; Local farmers }\end{array}$ \\
\hline $\begin{array}{l}\text { Insufficient environmental } \\
\text { management and governance capacity }\end{array}$ & Local administration & $\begin{array}{l}\text { Local administration; Environmental NGO; } \\
\text { State environmental institutions; Landowners; } \\
\text { Entrepreneurs; Farmers }\end{array}$ \\
\hline Limited coastal communication & Local administration & $\begin{array}{l}\text { Local administration; NGO; Local population; } \\
\text { Landowners; Entrepreneurs; } \\
\text { Local community organizations }\end{array}$ \\
\hline
\end{tabular}




\subsection{Stakeholder mapping and involvement in problem identification}

Identification and mapping of all stakeholders and institutions involved in the coastal governance is one of the key SAF elements and it is used to explore governance practices and build governance models. Social interviews of the selected 19 stakeholder representatives provided additional information for problem identification and supplemented material for the problem description and analysis. Expert material and outcomes from these interviews provided substantial content for the first discussions with the local stakeholders that took place during an interactive seminar. The seminar aimed at introducing the initial study results to the stakeholders involving them into discussion about coastal issues, as well as encouraging them to identify their interests and explore opportunities for the coastal resources conservation, protection, use and development. Participants of the stakeholders' seminar identified a number of impediments for sustainable management of their coastal territory. Most of the complaints related to restrictions for coastal management set by the national regulatory acts (particularly, in the fields of environment, health, construction, and entrepreneurship). As a result, the state of the coast and its quality is worsening. However, development of the coastal infrastructure is limited which causes such adverse effects as beach and dunes pollution, degradation of land cover, and fragmentation of biotopes. A secondary effect is insufficient access to the coast and the sea that results in inefficient use of opportunities and coastal resources for economic benefit. Moreover, restrictions in use of mechanical transport means behind the dunes and on the beach, influences the ways how the beach can be managed/cleaned and services provided for visitors. For instance, active tourism users cannot bring their equipment to the seashore. Coastal forests are improperly managed due to the overregulated protected nature zones. Construction restrictions limit or even completely block the opportunities to develop small infrastructure for sports, recreation, public facilities and infrastructure for people with special needs. Construction limitations have an impact on private housing and its extension. At the same time in some place the access to the sea is completely blocked due to a new residential building with a fence system.

Besides, participants identified that communication with the municipal services in general is adequate, though it is not specifically related to the environmental or coastal issues. The municipal coastal management activities are very limited and the capacity to perform them is insufficient. Even though, the village's leader as an institution was recognized as an essential element of local governance, but practice shows that it is not used efficiently enough. Likewise, problems were identified in the field of waste management becauseof lack of control of the individual household's contracts for waste collection.

As a result of all previous study steps, the research team concluded that there is no uniform stakeholders' understanding on what are the real problems on the coast. There are few problems that are mainly disperse and place specific, however, they are also perceived differently by different people (stakeholders). On the other hand, there is no fierce critic existing in none of the stakeholder groups. Furthermore, unclear is the stakeholders' willingness to establish closer cooperation among themselves. Business interest in the cooperation is also inexplicit and quite weak, however, the municipality, as decisive factor, is not taking the lead in establishing public-private partnership. This justifies a need for an extensive and inclusive discussion with stakeholders so that to facilitate creation of a uniform vision for the role of each stakeholder group in identifying, using, protecting and developing coastal resources; it should be a central value of the municipality seeking for common benefit. The municipal thematic planning is an activating instrument and opportunity to address this issue and find consensus among stakeholders on the integration of their concerns and interests in the coastal development agenda.

In general, two essential conclusions were drawn after the coastal issues analysis. Firstly, there are few local coastal territories where resources are over exploited or used in the interests of a limited stakeholder group or even individuals, this creates additional stress on resources, as well as environmental pollution and distrust among other stakeholders. At the same time, there are local coastal territories where resources are undermanaged, causing risks for further degradation of coastal resources. Thus, the central problem to be analysed using the SAF approach is: limited and unsustainable coastal resource management at the local 
municipal level is hampering the local development and causing coastal degradation which is a threat to the sustainability of resources.

\subsection{System definition}

The main components of the Social-Ecological System (SES) were defined based on the sustainable development approach: coastal systems are based on interconnected elements of the complex resources system consisting of natural, cultural, socio-economic, and governance resources (systems). This concept of four systems served as a basis for the model development. "Concept of material flows" and "material assets" were selected as convenient and transferrable for the system modelling, if quantifiable parameters are used to measure flows. A number of hazards which may affect the system were identified. In general, the overall system is stable and it does not have large conflicts, though each separate component of the system is characterized by inner instability that may grow / resonate (Table 2).

Table 2 . Coastal social-ecological system components

\begin{tabular}{|c|c|c|}
\hline SES components & Material flows & Hazards \\
\hline $\begin{array}{l}\text { Main Ecological components: } \\
\text { 1. Shore line } \\
\text { 2. Beach and coastal dunes } \\
\text { 3. Valuable biotopes and habitats } \\
\text { 4. Coastal forests } \\
\text { 5. Marine resources (fish, algae) } \\
\text { 6. Water quality } \\
\text { 7. Weather conditions } \\
\text { 8. Sand and stones }\end{array}$ & $\begin{array}{l}\text { Main Ecological flows: } \\
\text { 1. Marine litter } \\
\text { 2. Nutrients flow (by natural } \\
\text { systems) } \\
\text { 3. Sediments } \\
\text { 4. Coastal erosion } \\
\text { 5. Floods } \\
\text { 6. Wind falls }\end{array}$ & $\begin{array}{l}\text { Ecological hazards induced out of } \\
\text { system: } \\
\text { - Climate risks (storms, extreme } \\
\text { weather conditions, floods, rain } \\
\text { falls) } \\
\text { - Ship pollution } \\
\text { - Algae blooming } \\
\text { - Fires ( forest) }\end{array}$ \\
\hline $\begin{array}{l}\text { Main Social components: } \\
\text { 1. Local people - permanent residents } \\
\text { 2. Local people (newcomers) } \\
\text { 3. Seasonal visitors (short and long term) } \\
\text { 4. Buildings for living } \\
\text { 5. Communal services } \\
\text { 6. Cultural heritage } \\
\text { 7. Educational institutions } \\
\text { 8. Local NGOs (number) } \\
\text { 9. Welfare conditions } \\
\text { 10. Education level } \\
\text { 11. Social equity } \\
\text { 12. Ccoastal security and civil protection }\end{array}$ & $\begin{array}{l}\text { Main Social flows (materials of } \\
\text { human origin): } \\
\text { 1. Human-born litter/municipal } \\
\text { waste } \\
\text { 2. Nutrients flow (human } \\
\text { induced in direct coastal } \\
\text { territories/ households) } \\
\text { 3. Communal waste flows } \\
\text { (waste, waters) } \\
\text { 4. Loss of traditions }\end{array}$ & $\begin{array}{l}\text { Social hazards: } \\
\text { - Brains outflow (loss of intelligent/ } \\
\text { active people) } \\
\text { - Disbelieve in democracy/voluntary } \\
\text { approach } \\
\text { - Urbanization and change of social } \\
\text { patterns }\end{array}$ \\
\hline $\begin{array}{l}\text { Main Economic components: } \\
\text { 1. Local business enterprises: large, small } \\
\text { 2. Variety of services (business/ } \\
\text { municipal) } \\
\text { 3. Municipal budget } \\
\text { 4. Local inhabitants' income } \\
\text { 5. Land market } \\
\text { 6. Ports }\end{array}$ & $\begin{array}{l}\text { Main Economic flows: } \\
\text { 1. Visitors/tourists flow } \\
\text { 2. Investment flows (private, } \\
\text { municipal, state) } \\
\text { 3. Value added (VA) }\end{array}$ & 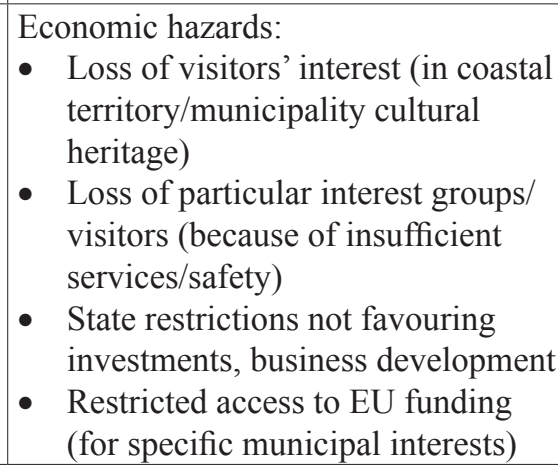 \\
\hline
\end{tabular}




\begin{tabular}{|c|c|c|}
\hline SES components & Material flows & Hazards \\
\hline $\begin{array}{l}\text { Main Governance components: } \\
\text { 1. Local administration capacity } \\
\text { 2. Local regulation acts } \\
\text { 3. Specific areas specialists } \\
\text { (environmental/nature/culture) } \\
\text { 4. Information/Participation mechanisms } \\
\text { (elderly institution; councils etc) } \\
\text { 5. NGOs (horizontal, village) } \\
\text { 6. Other governance instruments }\end{array}$ & $\begin{array}{l}\text { Main Governance flows: } \\
\text { 1.Environmental } \\
\text { Communication } \\
\text { 2. Specialists (on environment, } \\
\text { coast, nature, tourism) }\end{array}$ & $\begin{array}{l}\text { Governance hazards: } \\
\text { - } \text { Administrative territorial reform } \\
\text { - Conflict between local and national } \\
\text { development needs/interests } \\
\text { - } \text { Brain drain (loss of experienced } \\
\text { people) }\end{array}$ \\
\hline
\end{tabular}

In addition to the hazards, some knowledge gaps in governace were identified during the study:

- Lack of appropriate coastal management instruments at all levels of governance.

- Insufficient human/institutional capacity and focus on coastal issues.

- Low stakeholders' knowledge and public awareness, thus consequently interest, in efficient / sustainable use of the coastal resources / potential.

- Insufficient knowledge on harmonization of the national and the local level planning documents.

- Limited knowledge on local planning related to specific coastal issues and integrated coastal management (ICM).

- Limited knowledge about the coastal communication (instruments and practical implementation).

\subsection{Conceptual model}

A conceptual model was developed through multiple iterations. The research team based its approach on environmental management objectives, namely, on the coastal resources that were characterized by: state of biological diversity (protection); state of environmental quality; and sustainable use (state and quantity) of natural resources. At the same time these elements allowed to discuss ecosystem services that provide resources and environment quality necessary for social and economic activities. Besides, culture goals were added to ensure that a concept of the unified coastal "nature-culture heritage" is maintained according to the prevailing planning policy in in Latvia.

The coastal system comprises four systemic blocks: environmental, social, economic, and governance block; the latter has to become a central block in modelling exercise that allow to address an issue of "unsustainable governance of coastal resources". The incoming flows into each of the system's blocks could change the state of the system both in a positive or a negative direction. Namely, "Pollution flows impact" is negative (-). However, "Direct physical impact" might be positive or negative (+/-), i.e., a positive impact can be reached in this case by establishing an adequate coastal infrastructure and restoration activities of the coastal environment.

There are certain factors of the systems, which influence the system's behaviour, and which we set in the center as "Environmental action models".

The further logic of the analysis related to the external sub-systems that make impact on the main systems:

1) Local economic system and its activities.

2) Local Social system, the central element of which is households and their management practices or environmental activities.

3) Economic activities caused by the external factors and affecting the municipality (in Figure 3 described as Economic Transit System), the importance of this element is determined by a specific location of the Salacgriva municipality.

4) Marine litter as a globally emerging issue and also specifically on the Salacgriva coast. 
5) External natural system (formed due to climate change, also identified as an external hazard). Their impact is witnessed by coastal erosion and algae blooming that cause direct social and economic impact (impact on tourists during the season, etc.).

The coastal SES provides benefits for local economy and society (positive impact on the social system). One may expect return from the economic system in a form of investments in the development of the coastal / public infrastructure, and return from the social system impact in a form of the human resources/ specialists inflow. This return happens if appropriate environmental governance instruments, both at the national level and the local level, are in place. Besides, the impact of the international / EU environmental agreements, requirements and governance instruments should be taken into account as well.

Therefore, by setting the factor "Environmental action models" in the center of the system, there are created links between environmental governance and governance instruments, which are at the disposal or should be developed by the municipal administration to influence directly the stakeholders' actions and chosen behavioural models. The impact that is created using specific governance models and instruments influence stakeholders and push them towards the desired environmentally friendly activities/behaviours. Moreover, stakeholder groups that represent local social, economic systems and the economic transit system by "crossing" the action block are also influenced to determine the level of environmental friendliness of their actions. It has a positive direct impact on reduction of pollution and depletion of coast / resources.

The environmental governance system (both at the national and local level) influences social and economic systems through "environmental activities", one of which is generally named as "environmental protection regime of the coastal ecosystems" and is separately set, as this regime is a 'top-down' management instrument (including the municipal thematic coastal plan, municipal regulatory acts related to the coastal area, etc.).

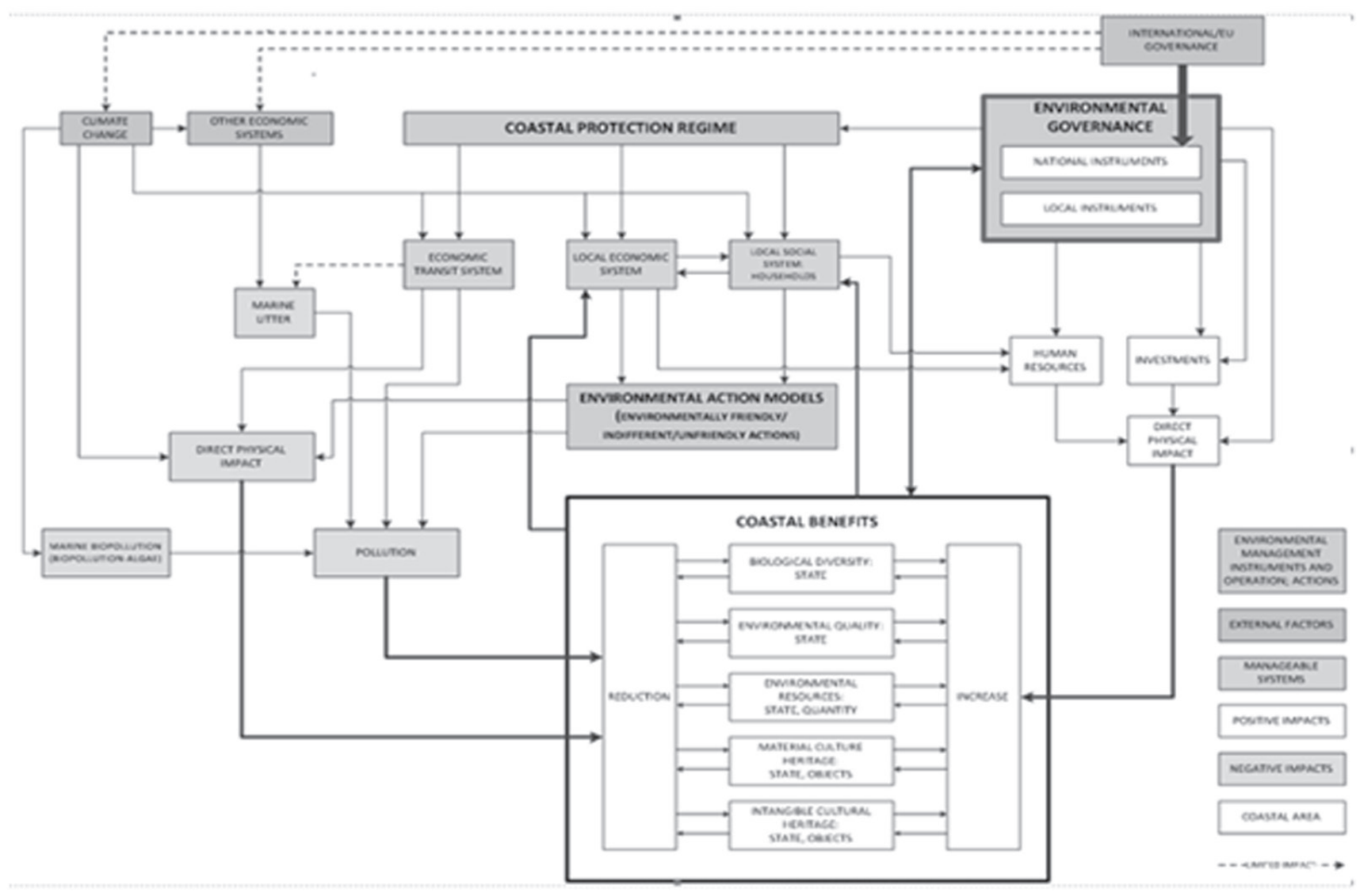

Figure 3. Conceptual model: results of the $1^{\text {st }}$ iteration 
During the second phase of the Conceptual model construction process - construction of a mathematical model - the research team actually increased the complexity and number of elements in subsystems. As a result, more variables and parameters were found to describe the system elements. In addition, the expert team knowledge was brought from an extensive planning metadata analysis performed by the research team members. Besides, particular emphasis was put on the definition of a "Governance system" and its elements within the model (Figure 3). Further, for the model presentation in STELLA there was elaborated the programming language which now is to be tested.

\section{Conclusions}

In the Latvian context, it appeared to be essential to find ways how to organise coastal governance (the governance process and structure) in the coastal rural territories, which are characterised by a small number of residents and low population density, but a long coastline. It principally affects the way how a territory and its resources shall be managed / governed. In most of the rural coastal territories in Latvia local coastal governance is comparatively underdeveloped and limited that results in unsustainable use of the coastal resources, thus preventing local development and causing coastal degradation which remains a threat to sustainability of the resources.

However, limited capacity of the coastal municipality's administration (in terms of human resources and economic options) considerably affects the traditional "top-down" approach of the municipal governance realisation as well as its efficiency. The solution should be found in further development of the "bottom-up" governance models by strengthening the interaction of the "top-down" and "bottom-up" governance, i.e. collaboration in the governance development. The needs of the local coastal citizens interact with the needs of visitors and the wider society. Actually, it is necessary to find a balance between these needs. System Thinking and the application of System Analysis Framework (SAF) are tools that allow passing sequentially through various stages of the system analysis, thus arriving at the common denominator in the coast and coastal resources governance acceptable for all involved stakeholders.

The SAF application is an innovative task, especially for the governance systems. Based on the general approach of the SAF, the authors applied in the case analysis a specifically designed step-wise approach seeking to develop the coastal resource governance system. The problem analysis performed by the authors demonstrates application of the problem analysis methodology in a situation which is typical for Latvian rural coastal territories - there are not severely dominating problems in the majority of these territories, but there is relatively high amount of small problems which with important mutual synergy influence cause a multiplier effect. Finally, the authors arrived at the generic problems the solutions to which should be found focusing on the coastal governance system.

The conceptual definition of the Social-Ecological System is based on the sustainable development approach, which propose thatcoastal systems are based on interconnected elements of the complex resources system consisting of natural, cultural, socio-economic, and governance resources (systems). Thus, the concept of four systems served as a basis for the model development. The concepts of "material flows" and "material assets" were selected as the most convenient characteristics from the system's dynamics perspective so that it was easier to transfer them for the system modelling needs. However, a number of hazards was identified which may affect the system. In general, the overall coastal system is stable and it does not have large conflicts, though each separate component of the system show inner instability of the system which may grow/expand and resonate thus affecting the stability of the whole system.

The performed research and the paper was prepared with financial support of the BONUS programme project "A Systems Approach Framework for Coastal Research and Management in the Baltic" (BaltCoast). 


\section{References}

Aall, C., Groven K., Lindseth G. (2007). The Scope of Action for Local Climate Policy: The Case of Norway. Global Environmental Politics, Vol. 7 (2), p. 83-101.

Atkinson, R., Klausen, J. E. (2011). Understanding Sustainability Policy: Governance, Knowledge and the Search for Integration. Journal of Environmental Policy \& Planning, Vol. 13, Issue 3, p. 231-251.

Baker, S., Eckerberg, K. (2008). Introduction: in Pursuit of Sustainable at the Sub- national Level: The 'New' Governance Agenda. In Pursuit of Sustainable Development: New Governance Practices at the Sub-national Level in Europe. Edited by S. Baker, K. Eckerberg. Routledge, p. 1-26.

Bubeck, P., Botzen, W. J. W., Kreibich, H., Aerts, J. C. J. H. (2013). Detailed Insights into the Influence of Flood-coping Appraisals on Mitigation Behaviour. Global Environmental Change.

Climate Change Adaptation Strategy of Salacgriva District (2011). Salacgriva, 31 p. (in Latvian). Available at: http:// www.salacgriva.lv/lat/salacgrivas novads/zalais novads/?text id=6401.

Coastal Spatial Development Guidelines 2011-2017. 20.04.2011, Riga: RL MEPRD (in Latvian). Available at: http:// polsis.mk.gov.lv/LoadAtt/file4375.docx.

Conrad, C. C., Hilchey, K. G. (2011). A Review of Citizen Science and Community-Based Environmental Monitoring: Issues and Opportunities. Environmental Monitoring Assessment. No. 176, p. 273-291.

Ernšteins, R., Antons, V., Stals, A., Lubuze, M., Šulga, D., Kursinska, S., Lice, E. (2012). Towards Complementary Municipal and Social Resilience Understanding: Stakeholder Training on Coastal Sustainability Governance and Communication. 12th International Multidisciplinary Scientific Geoconference SGEM 2012'. Proceedings, Bulgaria, Albena, p. 1007-1014.

Ernšteins, R., Kauliņšs, J., Līce, E., Štāls, A. (2011). Integrated Coastal Management for Local Municipalities in Latvia: Sustainability Governance and Indicator System. WIT Transaction, Vol. 149, p. 29-40.

Ernšteins, R., Lontone, A., Zvirbule, L., Antons, V., Zīlniece, I., Kauliņš, J., Vasariņa, L. (2012). Climate Change Adaptation Integration into Coastal Municipal Development: Governance Environment and Communication Preconditions. 12th International Multidisciplinary Scientific Geoconference SGEM 2012'. Bulgaria, Albena, Proceedings, Academy of Science of Bulgaria, p. 1077-1084.

Ernšteins, R., Lontone-Ieviņa, A., Kauliņšs, J., Zvirbule, L., Strazdiņš, J., Šteinberga, Z., Kudreņickis, I., Zīlniece, I., Kepals, A. (2014). Municipal Climate Change Adaptation Governance in Latvia: Approaching Cross-sectorial and Multi-instrumental Understanding. Journal of Regional Formation and Development Studies, Vol. 14, No. 3. Klaipeda: Klaipeda University, p. 40-52.

Hopkins, S. T., Bailly, D., Elmgren, R., Glegg, G., Sandberg, A., Støttrup, J. G. (2012). A Systems Approach Framework for the Transition to Sustainable Development: Potential Value Based on Coastal Experiments. Ecology and Society, Vol. 17 (3), p. 39.

Jansen, H., Ernsteins, R., Stottrup, J., Dinesen, G., Povilanskas, R., (2016). A Retrospective Analysis of Best Practice Integrated Coastal Management Cases Around the Baltic Sea. International conference, 7th European Coastal Lagoons Symposium. Vindicating the Biological and Socioeconomical Importance of Transitional Waters, Thesis compendium. Spain, Murcia.

Karpouzoglou, T., Dewulf, A., Clark, J. (2016). Advancing Adaptive Governance of Social-Ecological Systems through Theoretical Multiplicity. Environmental Science \& Policy. Vol. 57, p. 1-9.

Kudrenickis, I., Ernsteins, R., Kaulins, J. (2016). Sustainable Coastal Science-Policy-Practice Interface Development: Municipal Coastal Governance Indicator System. Environmental Science, No. 1, p. 255-264.

Mader, C. (2013). Sustainability Process Assessment on Transformative Potentials: The Graz Model for Integrative Development. Journal of Cleaner Production, No. 49, p. 54-63.

Mattor, K., Betsill, M., Huayhuaca, Ch., Huber-Stearns, H., Jedd, T., Sternlieb, F., Bixler, P., Luizza, M., Cheng, A. S. (2014). Transdisciplinary Research on Environmental Governance: A View from the Inside. Environmental Science \& Policy, Vol. 42. Colorado: Colorado State University, p. 90-100.

Meadows Dennis, L. (2004). Limits to Growth: The 30-Year Update. With Donella Meadows and Jørgen Randers, 363 p.

Mette, A., (2011). Bridging the Gap between Science and Society. In: P. Tett, A. Sandberf, A. Mette, editors. Sustainable Coastal Zone Systems, Dunedin Academic Press, Edinburgh, UK, p. 103-135.

Moles, R., Foley, W., Morrissey, J., O’Regan, B. (2008). Practical Appraisal of Sustainable Development Methodologies for Sustainability Measurement at Settlement Level. Environmental Impact Assessment Review, No. 28. p. 144-165.

Ostrom, E., Janssen, M. A., Anderies, J. M. (2007). Going beyond Panaceas. Proceedings of the National Academy of Science, Vol. 104 (39), p. 15176-15178.

Ostrom, E. (2009). A General Framework for Analysing Sustainability of Social-Ecological Systems. Science, No. 325, p. 419-422.

Salacgriva district council declaration on Green district. (2010). (In Latvian). 
Salacgriva District Sustainable Development Strategy 2015-2038 and Salacgriva district development programm 2015-2021. Salacgriva: Salacgriva District Council. (in Latvian).

Shaw, K., Theobald, K. (2011). Resilient Local Government and Climate Change Interventions in the UK Local Environment: The International Journal of Justice and Sustainability, No. 16, p. 1-15.

State Long Term Thematical Plan for the Development of Baltic Sea Coastal Public Infrastructure. (2016). RL MEPRD (in Latvian). Available at: http://polsis.mk.gov.lv/documents/5763.

Waagsaether, K., Ziervogel, G. (2012). Bridging the Communication Gap: An Exploration of the Climate Science-Water Management Interface. In W. Leal Filho (ed.), Climate Change and the Sustainable Use of Water Resources, Climate Change Management.

\title{
INTEGRUOTOS PAKRANČIŲ VALDYMO PLE்TROS STUDIJOS: SISTEMOS ANALIZÉS METODIKOS PRITAIKYMAS
}

\author{
Erika Lagzdina, Ivars Kudrenickis, Raimonds ERnsteins, Janis Kaulins \\ Latvijos universitetas (Latvija)
}

\section{Santrauka}

Tvaraus pakrančių valdymo būtinybė pripažįstama visame pasaulyje. Siekiant tokị valdymą užtikrinti, reikia integralumo tiek horizontaliu sektorių lygmeniu, tiek vertikaliu valdžios lygmeniu. Municipaliniu lygmeniu tvarus pakrančių valdymas daugelyje jūrinių valstybių kol kas nèra nei pakankamai išplètotas, nei ištirtas. Pakrančių valdyme dažnai susiduriama su labai paprastomis problemomis, bet jų sprendimai yra menkai suprantami municipaliniu lygmeniu ir nepritaikomi praktiškai socioekologinių sistemų tyrimai ir valdymas pakrančių teritorijose. Siekiant suprasti pakrančių valdymo struktūras ir jų veiksmus, būtina sistemingai mąstyti ir taikyti sistemų analizės metodus. Straipsnyje aprašytas gamtos mokslų pagrindais paremto sistemų analizès metodo (SAF) pritaikymas, kurio, mūsų žiniomis, dar niekas netaikė pakrančių valdymo sistemoms tirti. Autoriai adaptavimo metodą ir kaip tiriamajį objektą pasirinko Salacrigva savivaldybę Latvijoje. Tolesni žingsniai - galimų pakrančių plètros scenarijų kūrimas, taikant vadovavimo modelius, kurie remiasi tvarios plètros idejjomis, kai akcentuojama pakrančių išteklių ir gamtos apsauga bei vietinis socioekonominis vystymasis. Koncepcinis socioekologinès sistemos apibrèžimas paremtas tvarios plètros požiūriu: pakrantès matomos kaip tarpusavyje susiję dėmenys su sudètingomis išteklių sistemomis, kurias sudaro natūralios, kultūrinès, socioekonominès ir valdymo išteklių sistemos. Tad 4 sistemų konceptas tapo šio modelio kūrimo pagrindu. Materialiu ištekliu ir materialiu išlaidų terminai pasirinkti kaip tinkamiausi žvelgiant iš sistemų dinamikos perspektyvos, nes atrodè, kad jie labiausiai tenkina sistemos modeliavimo poreikius. Išskirtos kelios problemos, kurios gali paveikti sistemą. Iš esmès pakrančiu sistema yra stabili ir neturi didelių vidinių įtampos taškų, tačiau kiekvienas sistemos komponentas rodo vidinį nestabilumą, kuriam išaugus gali būti paveikta visa sistema.

Tyrimai ir šis straipsnis parengti BONUS programos projekto „Pakrančių tyrimų ir valdymo sistemų sandaros metodas Baltijos jūros regione" (BaltCoast)" lèšomis.

PAGRINDINIAI ŽODŽIAI: pakrančiu valdymas ir ištekliai, socioekologinè sistema, interesu grupès, sistemos analizès metodas.

JEL KODAI: Q, Q5, Q56, Q58 